\title{
Micro-nutrient Enriched Vermicompost by Coconut Coir Waste
}

\author{
S.S. Patil, M.C. Kasture* and R.V. Dhopavkar \\ Department of Soil Science and Agricultural Chemistry, Dr. B.S.K.K.V., \\ Dapoli 415 712, India
}

*Corresponding author

\begin{tabular}{l} 
Ke y w or d s \\
$\begin{array}{l}\text { Coconut, Cow } \\
\text { dung, Coir, } \\
\text { Earthworms }\end{array}$ \\
\hline Article Info \\
$\begin{array}{l}\text { Accepted: } \\
\text { 20 May 2018 } \\
\text { Available Online: } \\
\text { 10 June } 2018\end{array}$ \\
\hline
\end{tabular}

\section{A B S T R A C T}

The investigation entitled "Vermicomposting of coconut coir waste by utilizing epigeic earthworm species" was conducted at Centre of Excellence on Mango, Department of Horticulture, Dr.Balasaheb Sawant Konkan Krishi Vidyapeeth, Dapoli, during the Rabi season of 2015-16. Coir waste as a main substrate and cow dung are used as a waste material in different combinations such as M1-Coir waste (100\%), M2-Coir waste :cow dung- (80:20\%), M3- Coir waste :cow dung (60:40\%), M4- Coir waste :cow dung (40:60), M5- Coir waste :cow dung (20:80\%), M6- Cow dung (100\%) for preparation of vermicompost along with two species of earthworm's viz. Eudrilus euginae and Eisenia foetida. Based on the findings of present investigation, it could concluded that amongst the various combinations of organic residues evaluated, 100 per cent cow dung was found highest per cent recovery of vermicompost followed by 20:80 combination of coir waste and cow dung. The results of the experiment showed that on composting the $\mathrm{pH}$ of all organic residues decreased slightly during composting. There was gradual increase in electrical conductivity of composting materials from 30 DAI to the 180 DAI of composting. As far as the manurial value is concerned, 20:80 combination of coir waste and cow dung found to be the best combination from the point of Micro nutrient contents. Between the two species of earthworms, Eudrilus euginae species of earthworm found superior over Eisenia foetida species of earthworm in respect of most of the parameters studied. The manurial value of all the compost products improved due to vermicomposting.

\section{Introduction}

Coconut (Cocos nucifera L.) is cultivated in more than 93 countries of the world in 12.05 million hectares. Among these India occupies third place with 1.89 million hectares producing 12.821 million nuts/annum ${ }^{(15)}$. In
India, the annual production of coir waste is about 1.39 million tones and of all the states the Karnataka alone produces about 140-150 thousand tones. The generated waste is of great concern to the environment of our area as they are burnt. Further in order to alleviate the deleterious effects of inorganic fertilizers 
in the soil and environment, now-a-days scientists advocate development of novel technologies to produce organic manures from agro-industrial wastes. In recent years, earthworm has been identified as one of the important organisms to process the biodegradable organic matter. An important feature of vermicompost is that during the processes of various organic wastes by earthworms, many of the nutrients that the wastes contain are changed into plant usable forms ${ }^{(4)}$. Application of vermicompost to crop fields can improve the physico-chemical and biological properties of the soil (10). Vermicompost are the excreta of earthworm, which are capable of improving soil health and nutrient status. Vermiculture is a process by which all types of biodegradable wastes such as farm wastes, kitchen wastes, market wastes, bio-wastes of agro based industries, live-stock wastes etc. are converted while passing through the worm-gut to nutrient rich vermicompost. Vermin worms are used here act as biological agents to consume those wastes and to deposit excreta in the process called vermicompost.

Earthworms are well known natural machineries. They can transform organic waste materials into vermicompost for agricultural applications (3). During vermicomposting important organic nutrients are released by earthworms ${ }^{(5)}$. Generally earthworms are voracious feeders and they excrete a large part of these consumed materials in a semi digested form. According to Vermicomposts contain plant growth hormones, plant growth regulating substances and humic acids which enhance plant growth and productivity ${ }^{(2)}$. Therefore vermicomposts are widely used in organic farming. Out of the thousands of species of earthworms, only a few are suitable for vermicomposting of organic wastes. The epigeic species of earthworms are widely used for vermicomposting of different organic wastes.
E. eugeniaeis a large worm that grows extremely rapidly and is reasonably prolific and under optimum conditions it would be ideal for animal feed protein production. The epigeic earthworm species Eisenia foetidais a suitable earthworm species for vermicomposting which have short life cycle, small size and high rate of conversion of organic wastes as well as reproduction ${ }^{(12)}$.

Now days, it is very essential to protect the environment from further degradation, develop appropriate technologies for recycling various organic wastes and to harness the energy for minimizing environmental stress. Vermitechnology is a promising technique that has shown its potential in certain challenging areas like augmentation of food production, waste recycling, management of solid waste etc. ${ }^{(17)}$.

It is therefore imperative to convert the different waste to generate in huge amount to produce good quality vermicompost with minimum period of time. Take this into consideration the present study "Vermicomposting of coconut coir waste by utilizing epigeic earthworm species" is being undertaken with following objectives: Percent recovery of prepares vermicompost, Changes in chemical properties during vermicomposting and Changes in Micronutrient content during vermicomposting.

\section{Materials and Methods}

This study was conducted at Centre of Excellence for Mango, Department of Horticulture, Dr. Balasaheb Sawant Konkan Krishi Vidyapeeth, Dapoli during the Rabi season of 2015-16 for 180 days. Coconut coir i.e. coir waste (Cocosnucifera L.) was used as a main substrate and cow dung waste was used as a waste material in different combinations for preparation of vermicompost as $\mathrm{M}_{1}$-Coir 
waste (100\%), $\mathrm{M}_{2}$-Coir waste: cow dung(80:20 \%), $\mathrm{M}_{3^{-}}$Coir waste: cow dung (60:40\%), $\mathrm{M}_{4}$ - Coir waste: cow dung (40:60), $\mathrm{M}_{5}$ - Coir waste: cow dung (20:80\%), $\mathbf{M}_{6-}$ Cow dung (100\%). The earthworm species Eudriluseuginae and Eisenia foetida utilized for vermicomposting. The species Eudriluseuginae were brought from M/s. Institute of Natural Organic Agriculture, Pune and Eisenia foetida were brought from VanashriAgrotech, Pune. Vermicomposting was performed in plastic pots. The pots were first thoroughly cleaned with water and two holes were kept at the bottom side of the pots for drainage purpose and then rinsed with distilled water before using for vermicomposting.

\section{Layering of organic residues}

Bottom of the pot was covered with a layer of bricks as a bedding material. Immediately above a layer of well mixed partially decomposed waste material as per the respective combination of the treatment was spread and was sufficiently moistened to maintain the moisture around 50 per cent. Then the pots were covered with gunny bags to maintain adequate moisture and body temperature of earthworms and to protect against termites, ants and rats. The organic residues were watered regularly so as to maintain an optimum moisture level of 50 per cent for a period of 180 days.

\section{Inoculation of earthworms}

After sufficient watering of the vermibeds layer (waste material combination) to 50 per cent moisture content, two hundred earthworms of Eudriluseuginae and Eisenia foetida species were introduced as per treatment as an optimum inoculating density in the vermibeds of each pots. The material in the tubs was turned over manually at an interval of one month. Optimum moisture level of 50 per cent and average relative humidity was maintained throughout the period of composting.

\section{Incubation study}

To understand the nutrient release pattern, changes in chemical properties of compost under the influence of earthworms and time of composting, an incubation study was conducted for 180 days in Factorial Randomized Block Design comprising of six treatment combinations with two species of earthworms replicated three times.

The vermicompost samples from three randomly and well distributed spots in each treatment combinations were collected with the augur without disturbing the live worms at 30 DAI, 60 DAI, 90 DAI, 120 DAI, 150 DAI, and 180 DAI of vermicomposting and treatment wise vermicompost samples were prepared by mixing.

$\mathrm{pH}, \mathrm{EC}$, Percent Recovery and Micronutrients were determined from dried samples which were prepared by air drying in shade.

\section{pH}

$\mathrm{pH}$ of vermicompostsamples was determined with the help of digital $\mathrm{pH}$ meter having combined electrode with thermo probe using 1:10 compost:water suspension ratio ${ }^{(7)}$.

\section{Electrical conductivity $\left(\mathrm{dSm}^{-1}\right)$}

The electrical conductivity of vermicompost samples was determined from clear supernatant of overnight kept 1:10 compost: water ratio with the help of conductivity meter $^{(7)}$.

\section{Micronutrients (Fe, Mn, $\mathrm{Cu}$ and $\mathrm{Zn}$ )}

Micronutrients of vermicompost samples were determined from di-acid extract by Atomic Absorption Spectrophotometry method ${ }^{(11)}$. 


\section{Statistical analysis}

Statistical analysis of the data was carried out by Factorial Randomized Block Design as given by Panse and Sukhatme ${ }^{(13)}$.

\section{Results and Discussion}

\section{Percent recovery of vermicompost after completion}

It was reported that within the combination of coir waste and cow dung, treatment $\mathrm{M}_{6}$ found highest percent recovery i.e. 64.17 percent followed by the treatment $\mathrm{M}_{5}$ i.e. $(61.33 \%)$. Treatment $\mathrm{M}_{6}$ found significantly superior within all the treatment of the organic material combinations. Regarding the different earthworm species used, it was observed that the Eudriluseuginae found significantly superior over Eisenia foetida in percent recovery of vermicompost. However, the interaction effect of both i.e. combination of organic materials and earthworm species did not rich the level of significance regarding the percent recovery of vermicompost (Table 1).

\section{Changes in chemical properties during vermicomposting}

The chemical changes in vermicompost prepared with coir waste as a main substrate combined with cow dung were periodically studied at an interval of thirty days during vermicomposting it was observed that the $\mathrm{pH}$ was decreasing and Electrical conductivity was increasing with advancement of number of days from 30 to 180 DAI.

\section{pH}

It was observed that the $\mathrm{pH}$ was recorded minimum (6.33) at 180 DAI in $\mathrm{M}_{2}$ i.e. 80:20 proportion of coir waste and Cow dung and $\mathrm{M}_{6}$ i.e. Cow dung (100\%) has recorded maximum (6.94). Among the two earthworms species used $\mathrm{E}_{1}$ i.e. Eudrilluseuginae has maxmum $\mathrm{pH}$ (6.63) after 180 DAI than $\mathrm{E}_{2}$ i.e. Eisenia foetida (6.56). However, the interaction effects i.e. combination of organic materials and earthworm species was found non-significant throughout the period vermicomposting as shown in Table 2 . The shift in $\mathrm{pH}$ during the study could be due to microbial decomposition during the process of vermicomposting. From the data presented in table 2, it was observed that there was reduction in $\mathrm{pH}$ during the process of vermicomposing. While studying the vermicomposting of some organic residues concluded that the lower $\mathrm{pH}$ in end product (vermicompost) might be due to the production of $\mathrm{CO} 2$ and organic acids by microbial decomposition, during the process of bioconversion of different substrates in the beds ${ }^{(6)}$.

\section{Electrical conductivity $\left(\mathrm{dSm}^{-1}\right)$}

It was observed that the EC was recorded minimum $\left(0.81 \mathrm{dSm}^{-1}\right)$ at $180 \mathrm{DAI}$ in $\mathrm{M}_{1}$ i.e. coir waste $(100 \%)$ and $\mathrm{M}_{6}$ i.e. Cow dung $(100 \%)$ has recorded maximum $\left(1.49 \mathrm{dSm}^{-1}\right)$. Among the two earthworms species used $\mathrm{E}_{1}$ i.e. Eudrilluseuginae has maximum Electrical conductivity $\left(1.08 \mathrm{dSm}^{-1}\right)$ after 180 DAI than $\mathrm{E}_{2}$ i.e. Eisenia foetida $\left(1.01 \mathrm{dSm}^{-1}\right)$ as shown in Table 3.However, the interaction effects i.e. combination of organic materials and earthworm species was found nonsignificant throughout the period vermicomposting. From the data presented in table 3, it is evident that there was a considerable increase in electrical conductivity of all the different concentration of organic residues after their complete decomposition. The reasons attributed to this are the gradual increase in electrical conductivity may be attributed due to freely available ions of minerals that are generated during ingestion and extraction by the earthworms ${ }^{(18)}$. 
Changes in micronutrient content during vermicomposting

The primary nutrient content increased with advancement of days after inoculation From 30 DAI to 180 DAI for all the content of Fe, $\mathrm{Mn}, \mathrm{Cu}$ and $\mathrm{Zn}$ under the study.

\section{Total iron}

Among the six treatments treatment $\mathrm{M}_{5}$ i.e. 20:80 proportion of coir waste and cow dung combination has recorded maximum
Ironcontent i.e. $1714.33 \mathrm{ppm}$ at $180 \mathrm{DAI}$, i.e. at the end of composting whereas treatment $\mathrm{M}_{1}$ observed minimum iron content i.e. $1139.88 \mathrm{ppm}$.

Between two species of earthworm Eudriluseuginae was found to be significantly superior over Eisenia foetida in increasing iron content of the residues. The interaction effect of both i.e. combinations of coir waste: cow dung and earthworm species did not reach the level of significance on $30 \mathrm{DAI}$ as well as on 180 DAI of composting (Table 4).

Table.1 Percent recovery of vermicompost after completion

\begin{tabular}{|c|c|c|c|c|}
\hline \multirow{2}{*}{\multicolumn{2}{|c|}{ Treatments details }} & \multicolumn{2}{|l|}{ Species of earthworms } & \multirow{3}{*}{$\begin{array}{l}\text { Mean } \\
47.89\end{array}$} \\
\hline & & \multirow{2}{*}{$\begin{array}{l}\text { Eudriluseuginae }\left(\mathbf{E}_{1}\right) \\
48.44\end{array}$} & \multirow{2}{*}{$\begin{array}{l}\text { Eisenia foetida }\left(\mathbf{E}_{2}\right) \\
47.89\end{array}$} & \\
\hline $\mathrm{M}_{1}$ & Coir waste $(100 \%)$ & & & \\
\hline $\mathbf{M}_{2}$ & Coir waste:cow dung (80:20) & 50.77 & 49.89 & 50.33 \\
\hline $\mathbf{M}_{3}$ & Coir waste: cow dung $(60: 40)$ & 54.44 & 53.22 & 53.83 \\
\hline $\mathbf{M}_{4}$ & Coir waste: cow dung (40:60) & 57.22 & 55.66 & 56.44 \\
\hline $\mathbf{M}_{5}$ & Coir waste: cow dung $(20: 80)$ & 61.55 & 61.11 & 61.33 \\
\hline $\mathrm{M}_{6}$ & Cow dung $(100 \%)$ & 64.78 & 63.55 & 64.17 \\
\hline \multirow{2}{*}{\multicolumn{2}{|c|}{ Mean }} & 56.20 & 55.13 & \\
\hline & & M & $\mathrm{E}$ & M X E \\
\hline \multicolumn{2}{|c|}{ S.E. \pm} & 0.40 & 0.11 & 0.57 \\
\hline \multicolumn{2}{|c|}{ C.D. at $5 \%$} & 1.18 & 0.32 & NS \\
\hline
\end{tabular}

M-Material effect E-Earthworm effect NS- Non Significant

Table.2 Periodical changes in $\mathrm{pH}$ during composting of organic residues

\begin{tabular}{|c|c|c|c|c|c|c|c|}
\hline \multirow{2}{*}{\multicolumn{2}{|c|}{ Treatment details }} & \multicolumn{3}{|c|}{30 DAI } & \multicolumn{3}{|c|}{$180 \mathrm{DAI}$} \\
\hline & & \multirow{2}{*}{$\begin{array}{l}\mathbf{E}_{\mathbf{1}} \\
6.76\end{array}$} & \multirow{2}{*}{$\begin{array}{l}\mathbf{E}_{2} \\
6.75\end{array}$} & \multirow{2}{*}{$\begin{array}{l}\text { Mean } \\
6.76\end{array}$} & \multirow{2}{*}{$\begin{array}{l}\mathbf{E}_{1} \\
6.43\end{array}$} & \multirow{2}{*}{$\begin{array}{l}\mathbf{E}_{\mathbf{2}} \\
6.38\end{array}$} & \multirow{2}{*}{$\begin{array}{l}\text { Mean } \\
6.41\end{array}$} \\
\hline $\mathbf{M}_{1}$ & Coir waste $(100 \%)$ & & & & & & \\
\hline $\mathbf{M}_{2}$ & Coir waste:cow dung $(80: 20)$ & 6.61 & 6.56 & 6.59 & 6.32 & 6.35 & 6.33 \\
\hline $\mathrm{M}_{3}$ & Coir waste:cow dung (60:40) & 6.78 & 6.73 & 6.76 & 6.52 & 6.39 & 6.45 \\
\hline $\mathrm{M}_{4}$ & Coir waste:cow dung (40:60) & 6.81 & 6.82 & 6.82 & 6.66 & 6.48 & 6.57 \\
\hline $\mathbf{M}_{5}$ & Coir waste:cow dung $(20: 80)$ & 6.88 & 6.85 & 6.87 & 6.87 & 6.84 & 6.86 \\
\hline $\mathbf{M}_{6}$ & Cow dung (100\%) & 7.03 & 6.96 & 6.99 & 6.99 & 6.89 & 6.94 \\
\hline \multirow{2}{*}{\multicolumn{2}{|c|}{ Mean }} & 6.81 & 6.78 & & 6.63 & 6.56 & \\
\hline & & M & $\mathrm{E}$ & $\mathrm{M} \times \mathrm{E}$ & M & $\mathrm{E}$ & $\mathrm{MxE}$ \\
\hline \multicolumn{2}{|c|}{ S.E. \pm} & 0.01 & 0.01 & 0.02 & 0.03 & 0.02 & 0.04 \\
\hline \multicolumn{2}{|c|}{ C.D. at 5\% } & 0.04 & 0.03 & NS & 0.09 & 0.06 & NS \\
\hline
\end{tabular}

M-Material effect $\quad$ E - Earthworm effect NS- Non Significant 
Table.3 Periodical changes in iron content during composting of organic residues

\begin{tabular}{|c|c|c|c|c|c|c|c|}
\hline \multirow{2}{*}{\multicolumn{2}{|c|}{ Treatment details }} & \multicolumn{3}{|c|}{30 DAI } & \multicolumn{3}{|c|}{$180 \mathrm{DAI}$} \\
\hline & & $\mathbf{E}_{1}$ & $\mathbf{E}_{2}$ & Mean & $\mathbf{E}_{1}$ & $\mathbf{E}_{2}$ & Mean \\
\hline $\mathbf{M}_{1}$ & Coir waste $(100 \%)$ & 0.57 & 0.55 & 0.56 & 0.84 & 0.78 & 0.81 \\
\hline $\mathbf{M}_{2}$ & Coir waste:cow dung (80:20) & 0.68 & 0.63 & 0.66 & 0.90 & 0.84 & 0.87 \\
\hline $\mathbf{M}_{3}$ & Coir waste:cow dung (60:40) & 0.73 & 0.71 & 0.72 & 0.96 & 0.93 & 0.95 \\
\hline $\mathbf{M}_{4}$ & Coir waste:cow dung (40:60) & 0.74 & 0.73 & 0.73 & 1.01 & 0.97 & 0.99 \\
\hline $\mathbf{M}_{5}$ & Coir waste:cow dung $(20: 80)$ & 0.80 & 0.79 & 0.80 & 1.19 & 1.13 & 1.16 \\
\hline $\mathrm{M}_{6}$ & Cow dung $(100 \%)$ & 0.84 & 0.79 & 0.82 & 1.55 & 1.43 & 1.49 \\
\hline \multicolumn{2}{|c|}{ Mean } & 0.73 & 0.70 & & 1.08 & 1.01 & \\
\hline & & M & $\mathrm{E}$ & $\mathrm{M} \times \mathrm{E}$ & M & $\mathrm{E}$ & $\mathrm{M} \times \mathrm{E}$ \\
\hline \multicolumn{2}{|c|}{ S.E. \pm} & 0.01 & 0.01 & .01 & 0.02 & 0.01 & 0.02 \\
\hline \multicolumn{2}{|c|}{ C.D. at 5\% } & 0.03 & 0.02 & NS & 0.05 & 0.02 & NS \\
\hline
\end{tabular}

M-Material effect $\quad$ E - Earthworm effect NS- Non Significant

Table.4 Periodical changes in Iron content during composting of organic residues

\begin{tabular}{|l|l|l|l|l|l|l|l|}
\hline & \multicolumn{3}{|l}{ 30 DAI } & \multicolumn{1}{l|}{ 180 DAI } \\
\hline Treatment details & E1 & E2 & Mean & E1 & E2 & Mean \\
\hline M1 & Coir waste (100\%) & 808.60 & 803.40 & 806.00 & 1152.50 & 1127.27 & 1139.88 \\
\hline M2 & Coir waste:cow dung (80:20) & 1091.13 & 1036.40 & 1063.77 & 1305.07 & 1295.43 & 1300.25 \\
\hline M3 & Coir waste:cow dung (60:40) & 1228.00 & 1184.60 & 1206.30 & 1347.00 & 1306.43 & 1326.72 \\
\hline M4 & Coir waste:cow dung (40:60) & 1382.07 & 1347.00 & 1364.53 & 1665.73 & 1636.93 & 1651.33 \\
\hline M5 Coir waste:cow dung (20:80) & 1462.60 & 1444.50 & 1453.55 & 1726.17 & 1702.50 & 1714.33 \\
\hline M6 Cow dung (100\%) & 1149.73 & 1128.47 & 1139.10 & 1513.63 & 1503.90 & 1508.77 \\
\hline Mean & 1187.02 & 1157.39 & & 1451.68 & 1428.74 & \\
\hline & M & E & M x E & M & E & M x E \\
\hline S.E. \pm & 12.46 & 5.24 & 17.62 & 10.92 & 3.42 & 15.45 \\
\hline C.D. at 5\% & 36.55 & 15.37 & NS & 32.03 & 10.03 & NS \\
\hline
\end{tabular}

M-Material effect $\quad$ E-Earthworm effect NS- Non Significant

Table.5 Periodical changes in Manganese content during composting of organic residues

\begin{tabular}{|c|c|c|c|c|c|c|c|}
\hline \multirow{2}{*}{\multicolumn{2}{|c|}{ Treatment details }} & \multicolumn{3}{|c|}{30 DAI } & \multicolumn{3}{|c|}{180 DAI } \\
\hline & & \multirow{2}{*}{$\begin{array}{l}\mathbf{E}_{\mathbf{1}} \\
109.33\end{array}$} & \multirow{2}{*}{$\begin{array}{l}\mathbf{E}_{\mathbf{2}} \\
107.20\end{array}$} & \multirow{2}{*}{$\begin{array}{l}\text { Mean } \\
108.27\end{array}$} & \multirow{2}{*}{$\begin{array}{l}\mathbf{E}_{1} \\
182.43\end{array}$} & \multirow{2}{*}{$\begin{array}{l}\mathbf{E}_{2} \\
177.47\end{array}$} & \multirow{2}{*}{$\begin{array}{l}\text { Mean } \\
179.95\end{array}$} \\
\hline $\mathbf{M}_{1}$ & Coir waste $(100 \%)$ & & & & & & \\
\hline $\mathbf{M}_{2}$ & Coir waste:cow dung (80:20) & 85.73 & 84.93 & 85.33 & 167.77 & 166.70 & 167.23 \\
\hline $\mathbf{M}_{3}$ & Coir waste:cow dung (60:40) & 90.03 & 89.30 & 89.67 & 175.67 & 175.00 & 175.33 \\
\hline $\mathbf{M}_{4}$ & Coir waste:cow dung (40:60) & 93.53 & 91.40 & 92.47 & 189.43 & 188.87 & 189.15 \\
\hline $\mathbf{M}_{5}$ & Coir waste:cow dung $(20: 80)$ & 97.40 & 96.97 & 97.18 & 191.47 & 191.03 & 191.25 \\
\hline $\mathrm{M}_{6}$ & Cow dung (100\%) & 79.90 & 78.60 & 79.25 & 115.67 & 115.23 & 115.45 \\
\hline \multirow{2}{*}{\multicolumn{2}{|c|}{ Mean }} & 92.66 & 91.40 & & 170.41 & 169.05 & \\
\hline & & M & $\mathrm{E}$ & $M \times E$ & M & $\mathrm{E}$ & $M \times E$ \\
\hline \multicolumn{2}{|c|}{ S.E. \pm} & 0.66 & 0.21 & 0.94 & 0.69 & 0.52 & 0.98 \\
\hline \multicolumn{2}{|c|}{ C.D. at $5 \%$} & 1.95 & 0.62 & NS & 2.03 & 1.51 & NS \\
\hline
\end{tabular}

M-Material effect $\quad$ E-Earthworm effect NS- Non Significant 
Table.6 Periodical changes in Copper content during composting of organic residues

\begin{tabular}{|c|c|c|c|c|c|c|c|}
\hline \multirow{2}{*}{\multicolumn{2}{|c|}{ Treatment details }} & \multicolumn{3}{|c|}{30 DAI } & \multicolumn{3}{|c|}{180 DAI } \\
\hline & & \multirow{2}{*}{$\begin{array}{l}\mathbf{E}_{1} \\
40.70\end{array}$} & \multirow{2}{*}{$\begin{array}{l}\mathbf{E}_{\mathbf{2}} \\
39.40\end{array}$} & \multirow{2}{*}{$\begin{array}{l}\text { Mean } \\
40.05\end{array}$} & \multirow{2}{*}{$\begin{array}{l}\mathbf{E}_{\mathbf{1}} \\
50.30\end{array}$} & \multirow{2}{*}{$\begin{array}{l}\mathbf{E}_{\mathbf{2}} \\
49.07\end{array}$} & \multirow{2}{*}{$\begin{array}{l}\text { Mean } \\
49.68\end{array}$} \\
\hline $\mathbf{M}_{1}$ & Coir waste $(100 \%)$ & & & & & & \\
\hline $\mathbf{M}_{2}$ & Coir waste:cow dung $(80: 20)$ & 38.10 & 36.73 & 37.42 & 57.50 & 55.87 & 56.68 \\
\hline $\mathbf{M}_{3}$ & Coir waste:cow dung $(60: 40)$ & 48.20 & 47.57 & 47.88 & 56.70 & 56.07 & 56.38 \\
\hline $\mathbf{M}_{4}$ & Coir waste:cow dung $(40: 60)$ & 41.63 & 40.87 & 41.25 & 56.27 & 54.70 & 55.48 \\
\hline $\mathbf{M}_{5}$ & Coir waste:cow dung $(20: 80)$ & 47.17 & 46.40 & 46.78 & 78.27 & 77.10 & 77.68 \\
\hline $\mathbf{M}_{6}$ & Cow dung (100\%) & 62.93 & 60.97 & 61.95 & 87.63 & 85.73 & 86.68 \\
\hline \multicolumn{2}{|c|}{ Mean } & 46.46 & 45.32 & & 64.44 & 63.09 & \\
\hline & & M & $\mathrm{E}$ & $M \times E$ & M & $\mathrm{E}$ & $\mathrm{MxE}$ \\
\hline \multicolumn{2}{|c|}{ S.E. \pm} & 0.44 & 0.15 & 0.63 & 0.68 & 0.13 & 0.96 \\
\hline \multicolumn{2}{|c|}{ C.D. at 5\% } & 1.30 & 0.43 & NS & 1.98 & 0.38 & NS \\
\hline
\end{tabular}

M-Material effect E-Earthworm effect NS- Non Significant

Table.7 Periodical changes in zinc content during composting of organic residues

\begin{tabular}{|c|c|c|c|c|c|c|c|}
\hline \multirow{2}{*}{\multicolumn{2}{|c|}{ Treatment details }} & \multicolumn{3}{|l|}{30 DAI } & \multicolumn{3}{|c|}{180 DAI } \\
\hline & & \multirow{2}{*}{$\begin{array}{l}\mathbf{E}_{\mathbf{1}} \\
68.27\end{array}$} & \multirow{2}{*}{$\begin{array}{l}\mathbf{E}_{2} \\
66.70\end{array}$} & \multirow{2}{*}{$\begin{array}{l}\text { Mean } \\
67.48\end{array}$} & \multirow{2}{*}{$\begin{array}{l}\mathbf{E}_{\mathbf{1}} \\
91.20\end{array}$} & \multirow{2}{*}{$\begin{array}{l}\mathbf{E}_{\mathbf{2}} \\
89.37\end{array}$} & \multirow{2}{*}{$\begin{array}{l}\text { Mean } \\
90.28\end{array}$} \\
\hline $\mathrm{M}_{1}$ & Coir waste $(100 \%)$ & & & & & & \\
\hline $\mathbf{M}_{2}$ & Coir waste:cow dung $(80: 20)$ & 77.07 & 75.87 & 76.47 & 96.97 & 95.63 & 96.30 \\
\hline $\mathbf{M}_{3}$ & Coir waste:cow dung $(60: 40)$ & 89.90 & 89.23 & 89.57 & 109.03 & 100.83 & 104.93 \\
\hline $\mathbf{M}_{4}$ & Coir waste:cow dung (40:60) & 83.73 & 81.43 & 82.58 & 112.07 & 103.43 & 107.75 \\
\hline $\mathbf{M}_{5}$ & Coir waste:cow dung (20:80) & 95.10 & 91.53 & 93.32 & 153.57 & 141.90 & 147.73 \\
\hline $\mathrm{M}_{6}$ & Cow dung (100\%) & 116.63 & 114.00 & 115.32 & 153.73 & 141.50 & 147.62 \\
\hline \multirow{2}{*}{\multicolumn{2}{|c|}{ Mean }} & 88.45 & 86.46 & & 119.43 & 112.11 & \\
\hline & & M & $\mathrm{E}$ & $M \times E$ & M & $\mathrm{E}$ & $M \times E$ \\
\hline \multicolumn{2}{|c|}{ S.E. \pm} & 0.94 & 0.30 & 1.33 & 0.93 & 1.36 & 1.31 \\
\hline \multicolumn{2}{|c|}{ C.D. at 5\% } & 2.75 & 0.89 & NS & 2.72 & 4.00 & 3.84 \\
\hline
\end{tabular}

M-Material effect

E - Earthworm effect NS- Non Significant

The increase in $\mathrm{Fe}$ content with different combination over single substrate indicated accelerated mineralization with selective feeding by earthworms on material containing these metals ${ }^{(14,16,9)}$.

\section{Total manganese}

The changes in total manganese content of different organic residue found to be significant on $30 \mathrm{DAI}$ as well as on $180 \mathrm{DAI}$ of composting. At $180 \mathrm{DAI}$, i.e. at the end of composting, maximum manganese (191.25 ppm) was observed in treatment $\mathrm{M}_{6}$ i.e. $20: 80$ proportion of coir waste and cow dung combination, whereas treatment $\mathrm{M}_{6}$ i.e. 100 per cent cow dung observed minimum manganese content i.e. $115.45 \mathrm{ppm}$. At the end of composting Eudriluseuginae recorded maximum total manganese content.

During period of composting Eudriluseuginae species of earthworm found superior than those treated with Eisenia foetida species of earthworm. On 180 DAI i.e. at the end of composting both species found at par with each other. The interaction effect found nonsignificant at both stages (Table 5). 
Inoculation of either Eudriluseuginae or Eisenia foetida species caused increased in total manganese content of almost all the treatments. Jadiaand Fulekarobserved that the increase in total manganese content vermicomposting of vegetable waste with Eisenia foetida species of earthworm ${ }^{(9)}$. The variation in manganese content in cow dung, farm waste, local grass, cashew leaves and mango leaves was also noted by Jadhav ${ }^{(8)}$.

\section{Total copper}

The changes in total copper content of different organic residue found to be significant on $30 \mathrm{DAI}$ as well as on $180 \mathrm{DAI}$ of composting. At $30 \mathrm{DAI}$, regarding the different organic residue, it was observed that the maximum total copper $(61.95 \mathrm{ppm})$ in treatment $\mathrm{M}_{6}$ i.e. 100 per cent cow dung.

At 180 DAI, i.e. at the end of composting, maximum total copper (86.68 ppm) was observed in treatment $\mathrm{M}_{6}$ i.e. 100 per cent cow dung. Between two species of earthworm Eudriluseuginae (64.44 ppm) was found to be significantly superior over Eisenia foetida (63.09 ppm) in increasing copper content of the residues.

The interaction effect of both i.e. combinations of coir waste: cow dung and earthworm species did not reach the level of significance on $30 \mathrm{DAI}$ as well as on $180 \mathrm{DAI}$ of composting as shown in Table 6 .

Inoculation of either Eudriluseuginae or Eisenia foetida species caused increased in total manganese content of almost all the treatments. Jadiaand Fulekar (2008) observed that the increase in total manganese content vermicomposting of vegetable waste with Eisenia foetida species of earthworm. The variation in manganese content in cow dung, farm waste, local grass, cashew leaves and mango leaves was also noted by Jadhav ${ }^{(8)}$.

\section{Total zinc}

The changes in total copper content of different organic residue found to be significant on 30 DAI as well as on 180 DAI of composting. At $180 \mathrm{DAI}$, i.e. at the end of composting, maximum total zinc (147.73 $\mathrm{ppm})$ was observed in treatment $\mathrm{M}_{5}$ i.e.20:80 proportion of coir waste and cow dung, while minimum total Zinc (90.28 ppm) was recorded in treatment $\mathrm{M}_{1}$ i.e. 100 per cent coir waste. Treatment $\mathrm{M}_{5}$ and $\mathrm{M}_{6}$ were found at par with each other. Between two species of earthworm Eudriluseuginae was found to be significantly superior over Eisenia foetida in increasing zinc content of the residues. The interaction effect of both i.e. combinations of coir waste: cow dung and earthworm species did not reach the level of significance on 30 DAI. At 180 DAI, i.e. at the end of composting, maximum total zinc (153.73 ppm) was found in treatment $\mathrm{M}_{6}$ i.e. 100 per cent cow dung inoculated with earthworm species Eudriluseuginae while minimum total zinc (89.37 ppm) was recorded in treatment $\mathrm{M}_{1}$ i.e. 100 per cent coir waste inoculated with earthworm species Eisenia foetida.

The results are in agreement with those recorded by Jadia and Fulekar in vermicompost prepared with vegetable waste $^{(9)}$.

It could be concluded from the present investigation that amongst the various combinations of organic residues evaluated, cow dung (100\%) was found highest percent recovery of vermicompost followed by the treatment $\mathrm{M}_{5}$ (20:80 combinations of coir waste and cow dung. Among the two species of earthworms, Eudriluseuginae species of earthworm was found superior over Eisenia foetida species of earthworm in respect of most of the parameters studied. As far as the manurial value is concerned, 20:80 combinations of coir waste and cow dung was 
found to be the best combination from the point of micro nutrient contents. The manurial value of all the compost products was improved due to vermicomposting.

\section{Acknowledgement}

The author is grateful to Prof. R.V. Dhopavkar, Assistant Professor and M. C. Kasture, Associate Professor, Dept. of Soil Science and Agricultural Chemistry, College of Agriculture, Dapoli, for providing all help in this experiment.

\section{References}

1. Acharya, S. M. (2010).Comparative studies on physical and chemical changes during composting of organic residues as influenced by two species of earthworms and effective microorganisms. M.Sc. (Agri). Thesis submitted to Dr. B. S. Konkan Krishi Vidyapeeth, Dapoli. (Unpublished).

2. Arancon, N.Q., and Edwards, C.A., (2006).Effects of vermicomposts on plant growth. In: Proceedings of the Vermi-Technologies Symposium for Developing Countries, Department of Science and Technology-Phillippine Council for Aquatic and Marine Research and Development, Los Banos, Philippines.

3. Arancon, N.M., Edwards, C.A., Babenko, A., Cannon, J., Galvis, P., and Metzger, J.D.,(2008).Influences

of vermicompost, produced by earthworms and microorganisms from cattle manure, food waste and paper waste, on the germination, growth and flowering of petunias in the greenhouse. Appl. Soil Ecol., 25: 26-28.

4. Edwards, C.A (1988).Breakdown of animal, vegetable and industrial organic wastes by earthworms. In: Earthworms in wastes and Environment. Edited by C.A. Edwards, (SPB Academic publishing, Hague Netherlands.), Vol.24:21-31.

5. Edwards, C.A and Loft J.R (1995). The influence of cultivation on soil animal population progress in soil zoology. Edited by. J. Vanek, (Academia publishing home prague).

6. Haini,J.andHuhta,V.(1987).Comparison of composts produced from identical wastes by vermistabilization and convention compositng. Pedobiologia.30 (2): 137-144.

7. Jackson, M. L. (1973). Soil chemical analysis.Prentice Hall of India Pvt. Ltd., New Delhi, pp: 134-182.

8. Jadhav, V.S (1995) Studies on the physicochemical changes during humification of organic residues as influenced by earthworms. M.Sc(Agri) Thesis submitted to K.K.V, Dapoli.(Unpublished).

9. Jadia, C. D. and Fulekar, M. H. (2008).Vermicomposting of vegetable waste: A bio-physicochemical process based on hydro-operating bioreactor.African Journal of Biotechnology. 7(20), pp. 3723-3730.

10. Kale, D. (2006). Earthworm species for degradation of organic wastes. In: vermicompost - crown jewel of organic farming. Jayanthi publication, Banglore., pp: 17-20.

11. Lindsay, W.L and Norvell, W.A (1978). Development of DTPA soil test for $\mathrm{Zn}$, $\mathrm{Fe}, \mathrm{Mn}$ and $\mathrm{Cu}$. Soil Sci. Soc. Am. J. 42:421-428.

12. Nath G, Singh K, Singh DK. (2009) Effect of Different Combinations of Animal Dung and Agro/ Kitchen Wastes on Growth and Development of Earthworm Eisenia foetida. Australian J. Basi App. Sci3:3553-3556.

13. Panse, V. G. and Sukhatame, P.V. (1967). Statistical methods for Agricultural workers, ICAR, New Delhi. 
14. Prakash Mani, Karmegam Natchimuthu (2010). Dynamics of nutrients and microflora during vermicomposting of mango leaf litter (Mangiferaindica L.) using Perionyxceylanesis. Inte. J. Global Enviromental Issues. 10(314): 2010.

15. Rathinam, P. (2005). Steps for yield increase. Survey of Indian Agriculture.pp: 354.

16. Salvi, V.G (2007). Effect of green leaf manure and leaf litter compost of some forest tree species on soil properties and performance of rice-groundnut cropping sequence in lateritic soils of konkanregion. Ph.D (Agri.) Thesis submitted to Dr. B.S.K.K.V, Dapoli. (unpublished).

17. Tripathi, Y.C., Hazaria, P., Kaushik, P.K. and Kumar. A. (2005). Vermitechnology and waste management In:verms and vermitechnology A.P.H. publishing corporation, New Delhi, pp.9-21.

18. Viji, J. and Neelanarayanan, P. (2014). Earthworms mediated conversion of coir waste (Cocosnucifera L.) predigested with Pleurotus sp. under monoculture and polyculture conditions. International Journal of Recent Scientific Research, 5(1):269-276.

\section{How to cite this article:}

Patil, S.S., M.C. Kasture and Dhopavkar, R.V. 2018. Micro-nutrient Enriched Vermicompost by Coconut Coir Waste. Int.J.Curr.Microbiol.App.Sci. 7(06): 2352-2361. doi: https://doi.org/10.20546/ijcmas.2018.706.281 